\title{
Different mutation patterns of Plasmodium falciparum among patients in Jimma University Hospital, Ethiopia
}

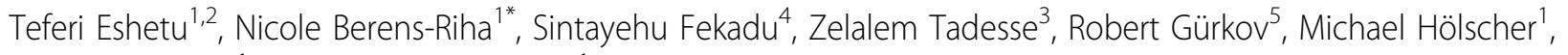
Thomas Löscher', Isabel Barreto Miranda'

\begin{abstract}
Background: The emergence of drug resistance is a major problem in malaria control. Combination of molecular genotyping and characterization of mutations or single nucleotide polymorphisms (SNPs) correlated with drug resistance can provide information for subsequent surveillance of existing and developing drug resistance patterns. The introduction of artemether/lumefantrine (AL) as first-line treatment, never used before in Ethiopia, allowed the collection of baseline data of molecular polymorphisms before a selection due to AL could occur.

Method: 97 patients with uncomplicated falciparum malaria were recruited from April to June 2006 and treated with either AL, quinine (Q) or atovaquone/proguanil (AP) in Jimma University Hospital, Ethiopia. Mutations or SNPs associated with resistance to these drugs were analysed by RFLP (pfdhfr, pfmdr1) and sequencing of the target genes (pfcytb, pfserca).

Results: SNPs previously reported to be associated with resistance to the study drugs were identified in recrudescent and treatment sensitive isolates. A total of seven recrudescences were obtained. The pfmdr1 N86Y mutation was found in $84.5 \%$ of isolates. The triple mutation $511,59 R, 108 \mathrm{~N}$ of the pfdhfr gene occured in high frequency (83.3\%) but no pfcytb mutation was detected. Sequencing showed a variety of previously described and new mutations in the pfserca gene.

Conclusion: The prevalence of mutations was in accordance with the expected patterns considering recent drug regimens. The broad introduction of $A L$ and the cessation of former drug regimens might probably change the current distribution of polymorphisms, possibly leading to decreased sensitivity to AL in future. Continuous surveillance of molecular patterns in this region is, therefore, recommended.
\end{abstract}

\section{Background}

Malaria is still one of the leading health problems in our time. Most cases and deaths occur in Sub-Saharan Africa. Malaria is endemic in large parts of Ethiopia including the town of Jimma and its surroundings with most cases occurring from September to December and April to June during and after the rainy seasons [1]. High levels of drug resistance of Plasmodium falciparum strains against anti-malarials, first chloroquine and later sulphadoxine/pyrimethamine (SP), resulted in new drug

\footnotetext{
* Correspondence: berens@|rz.uni-muenchen.de

'Department of Infectious Diseases and Tropical Medicine, Ludwig Maximilians University, Leopoldstrasse 5, 80802 München, Germany Full list of author information is available at the end of the article
}

policies in Ethiopia. In 2004, the first-line treatment recommendation was switched from SP to artemetherlumefantrine $(\mathrm{AL})$, an artemisinin-based combination therapy (ACT) [1-3]. Due to a shortage in supply, Quinine was used for several months instead. AL was introduced by the underlying study in this region. ACT combines the potential of rapid reduction of the parasite burden and elimination of remaining parasites due to longer-acting partner drugs [4]. The correlation between distinct SNPs and anti-malarial drug resistance or clinical outcome has been widely discussed. Mutations in the Plasmodium falciparum multi-drug resistance (pfmdr1) gene have been associated with resistance to chloroquine, quinine, mefloquine, lumefantrine and
Ciomed Central 
artemisinin [5-8]. Increased sensitivity to (Dihydro-) Artemisinin in the presence of wild type codon 86 in $p f m d r 1$ and in vivo selection of $p f m d r 86 \mathrm{~N}$ during $\mathrm{AL}$ treatment has been reported [9-12].

The target structure for artemisinins was first described by Eckstein et al in 2003, abandoning other theories about the mode of action. PfATP6, a SERCAtype ATPase (pfserca) of P. falciparum, is inhibited by artemisinins [13]. An L263E replacement and other mutations decreased sensitivity to artemisinins [14]. Since then, further resistance-related mutations concerning artemisinins have been detected in laboratory strains and field isolates associated with in vitro resistance [15-17]. Recent reports about high in vivo tolerance of artemisinin-based combination therapy (ACT) and artesunate monotherapy in Cambodia and Thailand are all the more alarming [18-20].

In this study, polymorphisms related to drug resistance were investigated. Mutations of the genes $p f m d r 1$ (codon 86) and pfdhfr (codon 16, 51, 59, 108, 164), the latter associated with proguanile resistance, were analyzed by RFLP. Regions in the pfserca and Plasmodium falciparum cytochrome B (pfcytb) gene related to artemether and atovaquone resistance, respectively, were sequenced.

\section{Methods}

\section{Study area and population}

The study was performed at the Jimma University (JU) Hospital in the city of Jimma, 1,700 m above sea level and $335 \mathrm{~km}$ south west of Addis Ababa, Ethiopia. Patients over five years of age (mean 19.1, range 6-50) with parasitologically proven uncomplicated falciparum malaria were recruited from April until June 2006. Written consent was obtained from either the patient or a parent/legal guardian. The study was conducted concomitantly with the previous published work on ototoxicity of artemether/lumefantrine in comparison with quinine and atovaquone/proguanil and was approved by the Jimma University Ethical Committee and is registered with Clinical Trial.gov, Number NCT00451139 [21].

\section{Procedures}

Blood samples were obtained at days 0,7 and 28 as well as on any day until day 90 in case of re-occurrence of symptoms suggesting malaria [22]. Aliquots of $10 \mu \mathrm{l}$ of capillary blood were spotted to Whatman $3 \mathrm{MM} \mathrm{Chr} \mathrm{fil-}$ ter paper, air dried, and stored at ambient temperature for later molecular analysis. The definition of the treatment outcome followed the WHO draft protocol for areas with low or moderate malaria transmission [2].

Parasite DNA was extracted from blood spots on the filter paper by the Chelex method [23]. The species was identified by nested polymerase chain reaction (PCR)
[24]. Single and multiple clone infections from day 0 were determined by amplification of $m s p 1$ and $m s p 2$ genes. To distinguish between re-infection and recrudescence, genotyping by amplification of $m s p 1, m s p 2$ and enzymatic digestion (RFLP) of the PCR products was performed between the pair of samples [25].

To amplify the $p f m d r 1$ and $p f d h f r$ gene, a nested PCR was used, the polymorphisms were detected by RFLP $[26,27]$. The PCR products were separated in $2 \%$ agarose gels stained with ethidium bromide and visualized under UV light. The regions of interest of the $p f c y t b$ and the pfserca gene were amplified by established PCR procedures $[28,29]$. The amplified gene fragments were purified from gel using Ultrafree-DNA extraction kit. Cycle sequencing was done with the BigDye Terminator Cycle Sequencing Kit and products analysed on the ABI3730 sequencer. Primers used for sequencing were those from the PCR. Sequences were verified using templates from two independent amplifications of the same DNA sample. Sequencing analysis was performed from both directions for each template. Sequences were analysed using the programme Bioedit and the NCBI blast function for comparison with sequences published in the GenBank database. (Reference strain for pfserca: Dd2, accession number: AB121053 and 3D7, acc no.: AL844501.1; for pfcytb: 3D7, acc. No.: AF069605)

\section{Results}

97 patients were included in the study with 30 patients receiving $\mathrm{AL}, 35 \mathrm{Q}$, and $32 \mathrm{AP}$. Clinical and parasitological efficacy as well as baseline data were described elsewhere in detail [21]. No treatment failure occured before or on day 7 in any treatment group. Until day 28, three patients in the Q group and two in the AP group presented with PCR-confirmed recrudescent falciparum malaria. Later, one recrudescence was detected in a patient in the Q group on day 40, and possibly another on day 70 in the AL group (Table 1).

The overall prevalence of $p f m d r 1$ mutations was high (84.5\%) (Table 2). In the Q group, all four treatment failures showed the $p f m d r 1$ mutation at codon $86 \mathrm{Y}$, but also $90.0 \%$ of the clinical sensitive samples presented with the mutation. In the AL group, four samples showed the wild type, one mixed (wild type and mutation); the remaining 25 samples exhibited only the mutation.

The expected high prevalence of the polymorphisms at codons $51 \mathrm{I}, 59 \mathrm{R}$, and $108 \mathrm{~N}$ of the $p f d h f r$ gene was found. Both recrudescent strains in the AP group showed the triple mutations (51I, 59R, 108N). The only A16V mutation in the AP group was found in the clinical symptomatic treatment failure (Table 1).

The pfserca gene was amplified and sequenced from the codons 230 to 463 and 600 to 790 . Sequencing was 
Table 1 Clinical and parasitological treatment failures

\begin{tabular}{|c|c|c|c|}
\hline PCR-corrected failure rates* & $A L$ & Q & AP \\
\hline $\begin{array}{l}\text { Number of patients with recrudescence/total number of patients } \\
\text { (day) }\end{array}$ & $1 / 30(70)^{* *}$ & $\begin{array}{l}4 / 35(24,28,28 \\
40)\end{array}$ & $2 / 32(28,28)$ \\
\hline Drug resistance associated polymorphisms & $\begin{array}{l}\text { 1. pfserca gene } \\
\text { 2. pfmdr codon } 86 \mathrm{~N}\end{array}$ & $\begin{array}{l}\text { 1. pfmdr codon } \\
86 \mathrm{~N}\end{array}$ & $\begin{array}{l}\text { 1. cytb gene codon } 268 \\
\text { 2. dhfr triple mutation }(511+59 \mathrm{R} \\
+108 \mathrm{~N}) \\
\text { 3. dhfr codon } \mathrm{A} 16 \mathrm{~V}\end{array}$ \\
\hline Polymorphisms in recrudescent samples n (\%) & $\begin{array}{l}\text { 1. } 0(0) \\
\text { 2. } 0(0)\end{array}$ & 1. $0(0)$ & $\begin{array}{l}\text { 1. } 0(0) \\
\text { 2. } 2(100) \\
\text { 3. } 1(50)\end{array}$ \\
\hline
\end{tabular}

*P. falciparum: Genotyping by PCR and RFLP patterns of the $m s p-1$ and $m s p-2$ gene

**Possible Recrudescence

intended for all 30 AL samples including the recrudescent strain, amplification failed due to long storage conditions of the DNA and general problems with these particular PCRs for the day 0 counterpart of the one possible recrudescent sample on day 70 and for many PCRs with the ATP1 and ATP2 primers. All gained sequences could be identified as part of the pfserca gene with the reference strain Dd2. 12 mutations or SNPs were identified, six new and six described. The previously reported $\mathrm{E} 431 \mathrm{~K}$ mutant codon was the most frequent occurring in seven isolates $[29,30]$. Each of the other genotypes was detected only once. No sample showed more than two mutations. Three of the new mutations were non synonymous and the other three synonymous (Tables 3 and 4). The sample from day 70 yielded no mutation in the pfserca gene.

No mutations were detected in the amplified regions of the $p f c y t b$ gene of 2 recrudescent strains in the AP group.

\section{Discussion}

High cure rates of AL have also been reported from other recent studies with 28 days of follow-up in Ethiopia [31,32]. For the detection of late recrudescences, follow-up periods longer than 28 days seem more appropriate. In this study, genotyping indicated a recrudescence on day 70 in one patient treated with AL. The msp-1 gene and especially the RFLP results with

Table 2 Prevalence of pfdhfr and pfmdr1 mutations

\begin{tabular}{ll}
\hline $\begin{array}{l}\text { Genetic } \\
\text { Polymorphism }\end{array}$ & $\begin{array}{l}\text { Overall prevalence rate mutation/total } \mathbf{n} \\
\text { (\%) }\end{array}$ \\
\hline DHFR A16V & $1 / 97(1.1)$ \\
DHFR N51I & $83 / 84^{*}(98.8)$ \\
DHFR C59R & $85 / 97(87.6)$ \\
DHFR S108N & $97 / 97(100.0)$ \\
DHFR S108T & $0 / 97(0.0)$ \\
DHFR (511,59R,108N) & $70 / 84(83.3)$ \\
DHFR I164L & $0 / 97(0.0)$ \\
pfmdr N86Y & $82 / 97(84.5)$ \\
\hline
\end{tabular}

*RFLP outcome not distinguishable for 13 samples different enzymes (Hinf III, Dde I, Rsa I) of the msp-2 gene showed the same molecular pattern for the two samples from day 0 and day 70 [25]. Additionally, a short sequence of the $m s p-1$ gene was amplified, as the amplification of the pfserca sequence failed. The two sequences fully matched, blasting showed a difference between the Ethiopian sequence and other published strains from different regions of 90-96\% [33]. Though, re-infection with a very similar clone not to be differentiated by molecular methods is still possible regarding the moderate transmission area. This particular molecular RFLP pattern was found in almost a quarter of all samples. Overall, at least six different patterns in different combinations, four being predominant, were observed. (Data not shown) The two particular samples from day 0 and day 70 showed the tyrosine mutation at codon 86 of the pfmdr1 gene.

Table 3 Prevalence of wild type and mutant codons in the pfserca gene

\begin{tabular}{lll}
\hline Codon & $\begin{array}{l}\text { Wild type } \\
\text { n (\%) }\end{array}$ & $\begin{array}{l}\text { Mutation } \\
\mathbf{n}(\%)\end{array}$ \\
\hline E237A & $6 / 7(85.7)$ & $1 / 7(14.3)$ \\
H243Y & $7 / 7(100.0)$ & $0 / 7(0.0)$ \\
L263E & $7 / 7(100.0)$ & $0 / 7(0.0)$ \\
L263L & $6 / 7(85.7)$ & $1 / 7(14.3)$ \\
L402V & $14 / 15(93.3)$ & $1 / 15(6.7)$ \\
E431K & $5 / 12(41.7)$ & $7 / 12(58.3)$ \\
N460N & $12 / 12(100.0)$ & $0 / 12(0.0)$ \\
A623E & $23 / 24(95.8)$ & $1 / 24(4.2)$ \\
A630S & $23 / 23(100.0)$ & $0 / 23(0.0)$ \\
R682R & $22 / 23(95.7)$ & $1 / 23(4.4)$ \\
N683E & $22 / 23(95.7)$ & $1 / 23(4.4)$ \\
N683K & $22 / 23(95.7)$ & $1 / 23(4.4)$ \\
K766K & $26 / 27(96.3)$ & $1 / 27(3.7)$ \\
K767E & $26 / 27(96.3)$ & $1 / 27(3.7)$ \\
K767R & $26 / 27(96.3)$ & $1 / 27(3.7)$ \\
S769N & $26 / 27(96.3)$ & $127(3.7)$ \\
K771E & $25 / 25(100.0)$ & $0 / 25(0.0)$ \\
K776N & $24 / 24(100.0)$ & $0 / 24(0.0)$ \\
\hline
\end{tabular}

Fragments spanning codons 230 to 463 and 600 to 790, respectively, ref. [29]) 
Table 4 List of pfserca non synonymous and synonymous mutations found

\begin{tabular}{|c|c|c|c|}
\hline Nucleotide mutation & $\begin{array}{l}\text { amino acid } \\
\text { (NS; Syn) }\end{array}$ & No. of mutations & Reference \\
\hline A709C & E237A & 1 & New \\
\hline C726T & $\mathrm{H} 243 \mathrm{Y}$ & 0 & 29 \\
\hline T787G, T788A & L263E & 0 & 29 \\
\hline A789G & L263L & 1 & New \\
\hline $1204 G$ & L402V & 1 & 29 \\
\hline G1291A & E431K & 7 & 29 \\
\hline T1380C & N460N & 0 & 30 \\
\hline C1867A & A623E & 1 & 29 \\
\hline G1887T & A630S & 0 & 29 \\
\hline A2045G & $R 682 R$ & 1 & New \\
\hline A2046G, T2048A & N683E & 1 & 29 \\
\hline T2048A & N683K & 1 & 30 \\
\hline A2297G & K766K & 1 & New \\
\hline A2298G & K767E & 1 & New \\
\hline A2299G & K767R & 1 & New \\
\hline G2305A & S769N & 1 & 29 \\
\hline A2310G & K771E & 0 & 29 \\
\hline G2327T & K776N & 0 & 29 \\
\hline
\end{tabular}

Fragments spanning codons 230 to 463 and 600 to 790 , respectively, ref. [29])

The previously described mutant codon $5769 \mathrm{~N}$ being associated with in vitro resistance in French Guiana was found in a clinical sensitive sample $[15,17]$. Other recently published mutations were not detected in the amplified regions of the study samples but the pfserca gene was only partly sequenced for 31 samples [34]. Overall, 12 different mutations were observed in an ALnaive population, some of these mutations seem to be globally distributed as reports from Asia and South Africa indicate and not to be associated with drug resistance or caused by drug pressure [34]. The next step will be the comparison of the polymorphisms in these isolates with about 350 P. falciparum samples, recently collected in Jimma area. Almost four years after the broad introduction of AL in Ethiopia, selection or disappearence of certain mutations may have occured.

A study conducted in southern Ethiopia prior to the introduction of ACTs showed a prevalence of $p f m d r 1$ $86 \mathrm{Y}$ of $81 \%$ and of the mutant pfcrt 76 of $100 \%$ [35]. High prevalence rates of the $p f m d r 1$ mutation $86 \mathrm{Y}$ were therefore expected. Q has been used for decades in Ethiopia as second line treatment and treatment for severe malaria, treatment failures occured sporadically. Exact data were not published. Due to intensive use in Thailand for example, failure rates with Quinine raised dramatically. Attempts to show a clear correlation of drug resistance with molecular patterns has failed so far, mutations in the pfmdr1 gene were discussed [36]. All treatment failures in the Q group showed the SNP of pfmdr 86Y associated with chloroquine resistance but increased sensitivity to quinine in in vitro studies. No selection to $86 \mathrm{~N}$ in the recrudescent samples was observed but the small sample size and few treatment failures allow no conclusions [37].

The high prevalence of $d h f r$ mutations is likely caused by wide use of proguanil, active metabolite of sulphadoxine/pyrimethamine, prior to AL introduction in the area. In the above cited study from Ethiopia, the $p f d h f r$ mutations N108, I51 and R59 were present in 100\%, $97 \%$ and $90 \%$, respectively, of all investigated samples, the $p f d h f r$ triple mutations $(51 \mathrm{I}+59 \mathrm{R}+108 \mathrm{~N})$ occurred in $87 \%$ of the isolates [35]. Another study from Jimma reported $100 \%$ prevalence of the $108 \mathrm{~N}$ and $51 \mathrm{I}$ mutations, and $54 \%$ prevalence of the pfdhfr triple mutation [38]. The occurrence of the triple mutations in both recrudescent isolates of the AP group was therefore very likely. Nevertheless, the idea of these mutations being a necessary but not sufficient cause of resistance to proguanil is supported. The circumstance that the only mutation at codon A16V occurred in the recrudescent sample may have contributed at least to the late treatment failure at day 28.

Although the combination AP has never been broadly used in the study region before, it simply served as negative control in the ototoxicity trial, two parasitological failures occurred, one was clinical symptomatic. Treatment failures have been reported from Africa. Some have been associated with mutations in the $c y t b$ gene, since in vitro resistance to AP was correlated especially with mutations at codon 268 of that gene [39-41]. A molecular survey from Ethiopia and Gabon detected no mutations in the pfcytb gene of samples from Ethiopia but several different mutations in $10 \%$ of Gabonian samples, although AP was not in use in both regions [42]. Spontaneous mutations are rare but seem to occure independent from drug pressure. Both recrudescent isolates in this study showed no mutations in the amplified sequence containing codon 268 but not the whole gene was sequenced and other mutations are possible. Treatment failures may also be due to limited bioavailability in some patients. However, as AP is highly recommended as prophylaxis for travellers to Ethiopia, a failure rate of $6.3 \%$ was quite alarming.

\section{Conclusion}

As expected, there were no signs of clinical or parasitological failures in the AL group except for one possible very late recrudescence on day 70 at the time of ACT introduction. The patterns of mutations in general fit with the situation of long-lasting chloroquine and SP usage before the presence of ACT in this area. Q is the national second-line treatment and backup, however its use will be compromised by the degree of resistance 
shown in our results. AL seems to be the best treatment option and must be available consistently. Moreover continuous surveillance should be established in the area for AL as data from South East Asia showed decreased susceptibility of $P$. falciparum for ACT several years after introduction. A similar development could possibly be expected in Ethiopia.

\section{Acknowledgements}

We thank Almaze Demissie from the Jimma Health Care Center and the staff of the Departments of Internal Medicine and the Departments of Pediatrics at Jimma University Hospital for support and assistance and participating patients for their cooperation, Erna Fleischmann for technical assistance; Menschen für Menschen foundation (Ethiopia) for logistic support. Financial support was received from the Friedrich- Baur-Stiftung, Munich; TE was supported by a research grant from the German Academic Exchange Service (DAAD).

\section{Author details}

'Department of Infectious Diseases and Tropical Medicine, Ludwig Maximilians University, Leopoldstrasse 5, 80802 München, Germany. ${ }^{2}$ Department of Microbiology, Parasitology and Immunology, Jimma University, Jimma, Ethiopia. ${ }^{3}$ Department of Paediatrics, Jimma University, Jimma, Ethiopia. ${ }^{4}$ Department of Internal Medicine, Jimma University, Jimma, Ethiopia. ${ }^{5}$ Department of Otorhinolaryngology, Head and Neck Surgery, Ludwig Maximilians University, Munich, Germany.

\section{Authors' contributions}

TE carried out the clinical study, participated in the molecular genetic studies and helped to draft the manuscript. NBR carried out the molecular genetic studies and the sequence alignment and drafted the manuscript. SF and ZT participated in the clinical studies. RG and MH participated in the design and coordination of the clinical study. TL was PI of the study, participated in its design and coordination. IBM coordinated and designed the study and helped to draft the manuscript. All authors read and approved the final manuscript.

\section{Competing interests}

The authors declare that they have no competing interests.

Received: 7 June 2010 Accepted: 7 August 2010

Published: 7 August 2010

\section{References}

1. World Health Organization: Malaria.[http://www.who.int/mediacentre/ factsheets/fs094/en/print.html].

2. World Health Organization: Guidelines for malaria treatment. 2006 [http:// www.who.int/malaria/docs/TreatmentGuidelines2006.pdf].

3. Abeku TA, van Oortmarssen GJ, Borsboom G, de Vlas SJ, Habbema JD: Spatial and temporal variations of malaria epidemic risk in Ethiopia: factors involved and implications. Acta Trop 2003, 87:331-340.

4. Krishna S, Uhlemann AC, Haynes RK: Artemisinins: mechanisms of action and potential for resistance. Drug Resist Updat 2004, 7:233-44.

5. Foot SJ, Thompson JK, Cowman AF, Kemp DJ: Amplification of the multidrug resistance gene in some chloroquine-resistant isolates of $P$. falciparum. Cell 1989, 57:921-30.

6. Price RN, Uhlemann AC, van Vugt $M$, Brockman $A$, Hutagalung $R$, Nair $S$, Nash D, Singhasivanon P, Anderson TJC, Krishna S, White NJ, Nosten F: Molecular and pharmacological determinants of the therapeutic response to artemether-lumefantrine in multidrug-resistant Plasmodium falciparum malaria. Clin Infect Dis 2006, 42:1570-1577.

7. Sidhu ABS, Valderramos SG, Fidock DA: pfmdr1 mutations contribute to quinine resistance and enhance mefloquine and artemisinin sensitivity in Plasmodium falciparum. Mol Microbiol 2005, 57:913-926.

8. Sisowath C, Ferreira PE, Bustamante LY, Dahlstrom S, Martensson A, Bjorkman A, Krishna S, Gil JP: The role of pfmdr1 in Plasmodium falciparum tolerance to artemether-lumefantrine in Africa. Trop Med Int Health 2007, 12:736-742.
9. Duraisingh MT, Jones P, Sambou I, von Seidlein L, Pinder M, Warhurst DC: The tyrosine- 86 allele of the pfmdr1 gene of Plasmodium falciparum is associated with increased sensitivity to the anti-malarials mefloquine and artemisinin. Mol Biochem Parasitol 2000, 108:13-23.

10. Sisowath C, Stromberg J, Martensson A, Msellem M, Obondo C, Bjorkman A, Gil JP: In vivo selection of Plasmodium falciparum pfmdr1 $86 \mathrm{~N}$ coding alleles by artemether-lumefantrine (Coartem). J Infect Dis 2005, 191:1014-1017.

11. Dokomajilar C, Nsobya SL, Greenhouse B, Rosenthal PJ, Dorsey G: Selection of Plasmodium falciparum pfmdr1 Alleles following Therapy with Artemether-Lumefantrine in an Area of Uganda where Malaria Is Highly Endemic. Antimicrob Agents Chemother 2006, 50:1893-1895.

12. Martensson A, Stromberg J, Sisowath C, Msellem MI, Gil JP, Montgomery SM, Olliaro P, Ali AS, Bjorkman A: Efficacy of artesunate plus amodiaquine versus that of artemether-lumefantrine for the treatment of uncomplicated childhood Plasmodium falciparum malaria in Zanzibar, Tanzania. Clin Infect Dis 2005, 41:1079-1086.

13. Eckstein-Ludwig U, Webb RJ, van Goethem DA, East JM, Lee AG, Mimura M, Bray PG, Ward SA, Krishna S: Artemisinins target the SERCA of Plasmodium falciparum. Nature 2003, 424:957-961.

14. Uhlemann AC, Cameron A, Eckstein-Ludwig U, Fischbarg J, Iserovich P, Zuniga FA, East M, Lee A, Brady L, Haynes RK, Krishna S: A single amino acid residue can determine the sensitivity of SERCAs to artemisinins. Nat Struct Mol Biol 2005, 12:628-629, Epub.

15. Jambou R, Legrand E, Niang M, Khim N, Lim P, Volney B, Ekala MT, Bouchier C, Esterre P, Fandeur T, Mercereau-Puijalon O: Resistance of Plasmodium falciparum field isolates to in-vitro artemether and point mutations of the SERCA-type PfATPase6. Lancet 2005, 366:1960-1963.

16. Afonso A, Hunt P, Cheesman S, Alves AC, Cunha CV, do Rosario V, Cravo P: Malaria parasites can develop stable resistance to artemisinin but lack mutations in candidate genes atp6 (encoding the sarcoplasmic and endoplasmic reticulum Ca2_ATPase), tctp, mdr1, and cg10. Antimicrob Agents Chemother 2006, 50:480-489.

17. Cojean S, Hubert V, Le Bras J, Durand R: Resistance to dihydroartemisinin. Emerg Infect Dis 2006, 12:1798-1799.

18. Wongsrichanalai C, Meshnick SR: Declining artesunate-mefloquine efficacy against falciparum malaria on the Cambodia-Thailand border. Emerg Infect Dis 2008, 14:716-719.

19. Noedl H, Se Y, Schaecher K, Smith BL, Socheat D, Fukuda MM: Artemisinin resistance in Cambodia 1 (ARC1) study consortium. Evidence of artemisinin-resistant malaria in western Cambodia. N Engl J Med 2008, 359:2619-2620.

20. Lim P, Alker AP, Khim N, Shah NK, Incardona S, Doung S, Yi P, Bouth DM, Bouchier C, Puijalon OM, Meshnick SR, Wongsrichanalai C, Fandeur T, Le Bras J, Ringwald P: Ariey: Pfmdr1 copy number and arteminisin derivatives combination therapy failure in falciparum malaria in Cambodia. Malar J 2009, 8:11.

21. Gürkov R, Eshetu T, Miranda IB, Berens-Riha N, Mamo Y, Girma T, Krause E, Schmidt M, Hempel JM, Löscher T: Ototoxicity of artemether/lumefantrine in the treatment of falciparum malaria: a randomized trial. Malar J 2008, 7:179.

22. Federal Democratic Republic of Ethiopia MoHAAE: Malaria diagnosis and treatment guidelines for health workers in Ethiopia., 22004.

23. Kain KC, Lanar DE: Determination of genetic variation within Plasmodium falciparum by using enzymatically amplified DNA from filter paper disks impregnated with whole blood. J Clin Microbiol 1991, 29:1171-1174.

24. Snounou G, Viriyakosol S, Zhu XP, Jarra W, Pinheiro L, do Rosario VE, Thaithong S, Brown KN: High sensitivity of detection of human malaria parasites by the use of nested polymerase chain reaction. Mol Biochem Parasitol 1993, 61:315-320.

25. Snounou G, Beck HP: The use of PCR genotyping in the assessment of recrudescence or reinfection after antimalarial drug treatment. Parasitol Today 1998, 14:462-467.

26. Jelinek T, Ronn AM, Lemnge MM, Curtis J, Mhina J, Duraisingh MT, Bygbjerg IC, Warhurst DC: Polymorphisms in the dihydrofolate reductase (DHFR) and dihydropteroate synthase (DHPS) genes of Plasmodium falciparum and in vivo resistance to sulphadoxine/pyrimethamine in isolates from Tanzania. Trop Med Int Health 1998, 3:605-609.

27. Flueck TPF, Jelinek T, Kilian AHD, Adagu IS, Kabagambe G, Sonnenburg F, Warhurst DC: Correlation of in vivo-resistance to chloroquine and allelic 
polymorphisms in Plasmodium falciparum isolates from Uganda. Trop Med Int Health 2000, 5:174-178.

28. Schwöbel B, Alifrangis M, Salanti A, Jelinek T: Different mutation patterns of atovaquone resistance to Plasmodium falciparum in vitro and in vivo: rapid detection of codon 268 polymorphisms in the cytochrome $b$ as potential in vivo resistance marker. Malar J 2003, 2:5.

29. Menegon M, Sannella AR, Majori G, Severini C: Detection of novel point mutations in the Plasmodium falciparum candidate gene for resistance to artemisinins. Parasitol Int 2008, 57:233-235.

30. Bertaux L, Quang LH, Sinou V, Thanh NX, Parzy D: New Pf mutations found in Plasmodium falciparum isolates from Vietnam. Antimicrob Agents Chemother 2009, 53:4570-4571.

31. Assefa A, Kassa M, Tadese G, Mohamed H, Animut A, Mengesha T: Therapeutic efficacy of Artemether/Lumefantrine $\left(\right.$ Coartem $\left.^{(\mathrm{R})}\right)$ against Plasmodium falciparum in Kersa, South West Ethiopia. Parasite Vectors 2010, 3:1.

32. Kefyalew $T$, Animut $A$, Tamene $T$, Jima D, Hailemariam A, Legesse M: Efficacy of six-dose regimen of artemether-lumefantrine for the treatment of uncomplicated falciparum malaria, three years after its introduction into Ethiopia. Parasite 2009, 16:129-134.

33. Basic Local Alignment Search Tool. [http://blast.ncbi.nlm.nih.gov/Blast.cgi].

34. Jambou R, Martinelli A, Pinto J, Gribaldo S, Legrand E, Niang M, Kim N, Pharath L, Volnay B, Ekala MT, Bouchier C, Fandeur T, Berzosa P, Benito A, Ferreira ID, Ferreira C, Vieira PP, Alecrim MG, Mercereau-Puijalon O, Cravo P: Geographic structuring of the Plasmodium falciparum sarco(endo) plasmic reticulum Ca2+ ATPase (PfSERCA) gene diversity. PLoS One 2010, 5:e9424.

35. Schunk M, Kumma WP, Miranda IB, Osman ME, Roewer S, Alano A, Löscher T, Bienzle U, Mockenhaupt FP: High prevalence of drug-resistance mutations in Plasmodium falciparum and Plasmodium vivax in southern Ethiopia. Malar J 2006, 5:54.

36. Farooq U, Mahajan RC: Drug resistance in malaria. J Vector Borne Dis 2004, 41(3-4):45-53.

37. Peel SA, Bright P, Yount B, Handy J, Baric RS: A strong association between mefloquine and halofantrine resistance and amplification, over expression, and mutation in the P-glycoprotein gene homolog (pfmdr) of Plasmodium falciparum in vitro. Am J Trop Med Hyg 1994, 51:648-658.

38. Gebru-Woldearegai T, Hailu A, Grobusch MP, Kun JF: Molecular surveillance of mutations in dihydrofolate reductase and dihydropteroate synthase genes of Plasmodium falciparum in Ethiopia. Am J Trop Med Hyg 2005, 73:1131-1134

39. Mulenga M, Malunga F, Bennett $S$, Thuma PE, Shulman C, Fielding $K$, Alloueche A, Greenwood BM: A randomised, double-blind, placebocontrolled trial of atovaquone-proguanil vs. sulphadoxinepyrimethamine in the treatment of malarial anaemia in Zambian children. Trop Med Int Health 2006, 11:1643-1652.

40. Kuhn S, Gill MJ, Kain KC: Emergence of atovaquone-proguanil resistance during treatment of Plasmodium falciparum malaria acquired by a nonimmune North American traveller to west Africa. Am J Trop Med Hyg 2005, 72:407-409.

41. Kessl JJ, Ha KH, Merritt AK, Lange BB, Hill P, Meunier B, Meshnick SR, Trumpower BL: Cytochrome $b$ mutations that modify the ubiquinolbinding pocket of the cytochrome bc1 complex and confer anti-malarial drug resistance in Saccharomyces cerevisiae. J Biol Chem 2005, 280:17142-17148.

42. Gebru T, Hailu A, Kremsner PG, Kun JF, Grobusch MP: Molecular surveillance of mutations in the cytochrome $b$ gene of Plasmodium falciparum in Gabon and Ethiopia. Malar J 2006, 5:112.

doi:10.1186/1475-2875-9-226

Cite this article as: Eshetu et al:: Different mutation patterns of

Plasmodium falciparum among patients in Jimma University Hospital, Ethiopia. Malaria Journal 2010 9:226.

\section{Submit your next manuscript to BioMed Central and take full advantage of:}

- Convenient online submission

- Thorough peer review

- No space constraints or color figure charges

- Immediate publication on acceptance

- Inclusion in PubMed, CAS, Scopus and Google Scholar

- Research which is freely available for redistribution

Submit your manuscript at www.biomedcentral.com/submit
Biomed Central 